\title{
A Model of Character Education as Reflected in Fuady's Negeri Lima Menara
}

\author{
By \\ Hendra Darmawan \\ English Department Study Program \\ Faculty of Teacher Training and Education \\ Ahmad Dahlan University Yogyakarta \\ Email: hendradar@yahoo.com
}

\begin{abstract}
ABSTRAK
Negeri Lima Menara oleh Fuady telah melanda bagi banyak pembaca. Novel ini bercerita tentang kehidupan di pesantren Islam. Kisah novel yang mencerminkan pengalaman penulis selama studi di Pondok Pesantren Darassalam Ponorogo, Jawa Timur pada tahun 1980. Madani Pesantren sebagai lembaga pendidikan utama di dalam menunjukkan peran dalam membangun karakter siswa dengan mengintegrasikan modernitas dan ajaran Islam pada saat yang sama.Fuady mencoba untuk menunjukkan model yang baik tentang bagaimana lembaga pendidikan (Madani Pondok Pesantren) dapat mendidik siswa untuk meningkatkan perkembangan pribadi mereka. Madani Pondok Pesantren memiliki sistem pendidikan yang baik dan tegas untuk bertanggung jawab atas perilaku siswa-nya dari dasar sampai dengan akhir proses pembelajaran. Artikel ini menganalisa peran Madani Pondok Pesantre dalam mengembangkan siswa bangunan karakter. penulis memperoleh beberapa temuan dari novel Negeri Lima Menara pada bagaimana pondok pesantren madani berhasil bisa mendidik siswa untuk memiliki karakter yang baik dengan mengoptimalkan peran guru sebagai motivator dan model yang baik bagi siswa; membangun ikatan emosional antara guru dan siswa; dan memberikan kesadaran dan nilai-nilai moral kepada siswa.
\end{abstract}

Kata kunci: Karakter, Pendidikan Karakter, Pelatihan terbaik.

\begin{abstract}
The Land of Five Towers by Fuady has been overwhelming for many readers. This novel tells about acquaintance and life in pesantren-Islamic boarding school. The story of that novel reflects the author experiences during his study in Pondok Pesantren Modern Darassalam Ponorogo, East Java in 1980. Madani Pesantren as the main educational institute inside shows its roles in building students' characters by integrating modernity and Islamic teachings at the same time.

Fuady tries to demonstrate a good model of how educational institution (Madani Pondok Pesantren) can educate its students to improve their personal developments. Madani Pondok Pesantren has good and firm educational systems to be in charge of its student's behaviors from the foundation up to the end of learning process.

This article analyzes the roles of Madani Pondok Pesantre in developing students' characters building. The writer obtains some findings from The Land of Five Towers on how Madani Pondok Pesantran could successfully educate its students to have good characters by optimizing the roles of teachers as motivators and good models for students; building emotional bond between teachers and students; and giving conscientiousness and moral values to the students.
\end{abstract}


Key words: Character, Character Education, Best Practice.

\section{INTRODUCTION}

Character education is one of the National Education goals (Sisdiknas Act Year 2003 article 1). National education goal is to develop student potencies to have intelligence, personality and morality. The central goal of character education is the development of character in students. Character can be defined in various ways and is indeed used in different ways in common speech. We consider someone "a character" if they act typically. We also commonly refer to "having character," but sometimes that character is "good" or "bad." It is unlikely that a school that proposes a charactereducation initiative is interested in either generating a "bunch of characters" or promoting the development of "bad character" in students. What we really mean in this field when we invoke character is socio-moral competency.
Character is the complex set of psychological characteristics that enable an individual to act as a moral agent. In other words, character is multifaceted. It is psychological. It relates to moral functioning. In the first author's moral anatomy, seven psychological aspects of character are identified: moral action, moral values, moral personality, moral emotions, moral reasoning, moral identity, and foundational characteristics (Berkowitz, 1997).

Marvin (2004) said that there are many research conducted before on character education, they fail in monitoring the level of accomplishment quality and sustainability. Almost all model of character education implemented in USA deals with the programs such as life skill, leadership skill, caring school community and etc.

Character education varies from a limited set of stand-alone and homegrown lessons to fully integrated, comprehensive school- 
reform models. Many teachers and/or schools simply generate some lessons or recognition programs for good character. Others adopt packaged curricula or programs those themselves may vary from a small set of lessons to a comprehensive school model including integration of character issues into their literature or social studies curriculum and so on.

Furthermore, Service learning, socialemotional learning, and prevention programs all share significant features with character education and could be considered forms of character education. Character education has been demonstrated to be associated with academic enthusiasm and aspirations, academic achievement, pro-social behavior, bonding to school, pro-social and democratic values, conflict-resolution skills, moralreasoning maturity, responsibility, respect, self-efficacy, self-control, self-esteem, social skills, and trust in and respect for teachers. Furthermore, effective character education has been demonstrated to reduce absenteeism, discipline referral, school failure, suspensions, school anxiety, and substance use.

Central of Muhammadiyah conceptualized the character as excellence values embodied in individuals that are articulated in their daily life as personality and identity (2009). Those individuals are having sort of identities such as being religious, moderate, intelligent, self help. The challenges of globalization era require the personal with competitiveness, progress, dynamics and excellences

Lickona (2007) defines character comprehensively to include thinking, feeling and behavior.

\section{Best Practice from Pesantren Modern}

\section{Darussalam}

The Land of Five Towers by Fuady has been remarkable for many readers of that novel. This novel tells about friendship and life in pesantren. The chronicle of that novel reflects the author experiences during his 
study in Pondok Pesantren Modern

Darassalam Ponorogo, East Java in 1980.

Alif, the main character had never set foot outside of West Sumatra. His mother wants him to attend Islamic boarding school, a pesantren, he dreams of public high school. Reluctantly, he follows his mother's wishes. On his first day at Madani Pesantren, Alis is captivated by the powerful phrase manjada wa jada. He who gives his all will surely succeed. United by punishment, he quickly becomes friends with five boys from across archipelago, and together they become known as the Fellowship of the Manara. Beneath the mosque's minaret, the boys gaze at the clouds on horizon, seeing in their individual dreams of far-away lands, like America and Europe.

Besides telling the Fellowship of Manara, this novel shows that Madani Pesantren as the main educational institution within that novel shows its roles in building students' characters by internalizing modernity and Islamic teachings at once.
Madani Pesantren appears with a new notion in which the concept of modernity (sciences, English and Arabic etc.) and traditional pesantren (no certificate for its graduates). Madani Pesantren can educate its students to improve not only their knowledge but also personal developments. The combinations of the strict regulations and good role models from teachers (Ustads) and Kyai are the keys of successful education in Madani Pesantren.

\section{Theory of Education}

Education is an important part of human developments. Educate is further defined as - to develop the knowledge, skill, or character of..." Thus, from these definitions, one can assume that the purpose of education is to develop the knowledge, skill, or character of students (Sociology of education). Education has huge responsibilities upon students' developments in terms of cognitive, affective and psychomotor aspects. 
Education also is the way for creating achievements and improvements. Education is the vehicle of knowledge, self-preservation and success. Education not only gives a platform to succeed, but also the knowledge of social demeanor, strength, character and self respect (Shekar and Emmaniel, 2012: 375). Mudyaharjo (2006: 3) defines education as the experiences of learning occupy in any kinds of environments and for life. In other words, education influences many aspects of human lives and social environments or even natural environments.

\section{Character Educations}

Lickona (1992) emphasizes some rationales why character education is urgent:

a. There is a clear and urgent need, as young people increasingly hurt themselves and others because of unawareness of and/ or indifference to moral values.

b. Transmitting moral values to the next generation is one of the most important functions of a civilization. c. The school's role as character educator is even more vital when millions of children get little moral teaching from parents, community or religious institutions.

d. Common ground exists on universally accepted moral values like caring, trust, respect and responsibility.

e. Democracies have a special need for moral education because democracy is a government of, for, and by people themselves.

f. There is no such thing as value-free education. Schools teach educational values, everyday values by design or default.

g. A commitment to character education is essential if we are to attract and keep good teachers.

h. Moral questions are among the greatest questions facing the individual and human race.

i. Effective character education makes schools more civil, caring 
communities and leads to improve academic performance.

The issue of character education rises

up currently. Parents, teachers, and government apprehend that knowledge and skills are not enough for students. They must be taught about morals, politeness, fairness, responsibility, discipline, and anything related to personality. The character education is a process which develops the real and positive perspectives, the attitudes towards other people, the ability to making decisions and the necessity to participate in the social activities in learners (Saghafi, 2012: 2). Backer (2012) says that at least six characters should be developed such as trustworthiness, respect, responsibility, fairness, caring and citizenship.

Character education in essence aims to form a tough, competitive nation, have good moral, noble, tolerance, speakers of brewers, soulless developing dynamic, patriotic, oriented to science and technology, which are all imbued by faith and committed to the Lord Almighty God based on Pancasila (Mohamad, 2012).

Josephson Institute (2012) gives the explanations for the six characters above. First, trustworthiness is a behavior that tends to be honest, reliable, loyal, and do right things. Second, respect is the way people show tolerance, accepting of differences, good manners and peace. Third, responsibility is what we are supposed to do; be self-disciplined; and be accountable for our words, actions, and attitudes. Fourth, fairness is the way we treat all people fairly and be open-minded. Fifth, caring is how people care and help to each other. To care somebody, people need to be kind and compassionate. The last is citizenship in which people get involved in community affairs and cooperate together for better environment.

\section{Roles of Education Institution and}

\section{Government Policy in Indonesia}

Educational Institutions have to optimize all elements to support teaching and 
learning processes. They must motivate teachers to educate students to develop their intellectuality and personality well. The teachers should treat their students with affection on a par with their own children to help them grow into integrated personalities of nation. A feeling of love and being loved by others, keeping in mind that a human being is a social animal, keeps a person going at the workplace (Shekar and Emmaniel, 2012: 380).

Indonesia has committed to Open Educational Resource (OER) as part of its strategy of serving the educational needs of a population of nearly 250 million spread over 17,000 islands and three time zones (Hoosen, 2012). To fulfill the needs of education, government must set a good and proper curriculum for students. Around 1980s, government was aware of religion as the basic step to educate morals to students, but it met challenges. There was a side who did not like with this policy, especially communist (Tomy, 2012). Then Islamic Educational
Institutions did not have strong law foundation to maintain the existences of Madrasahs until 1989 (Anasom, 2000: 68). It seems that government did not have any serious support yet to develop Islamic education as well.

Thus in developing curriculum, government just spotlight on cognitive aspects of students, meanwhile character buildings are marginalized. Curriculum does not comprise character buildings as subject that should be taught to student; moreover, religious lessons as the first way to initiate morals just get one meeting in a week. How can this nation develop characters of students as next generation without moral lesson as much as other subjects?

An alternative school is an educational setting designed to accommodate educational, behavioral, and/or medical needs of children and adolescents that cannot be adequately addressed in a traditional school environment (Jennifer, 2012). The alternative education tries to fulfill the additional needs 
that are not covered by common educational institutions..

\section{DISCUSSION}

\section{Pesantren as an alternative Education}

Indonesia has three kinds of educational institutions; they are school, madrasah, and pesantren. Pesantren has been identified originally educational institution from Indonesia. Different from school and madrasah, pesantren has been acknowledged with Islamic and indigenous originality, infect pondok pesantren is the oldest educational institution known in Indonesia (Jumhur, 2011). Pesantren is categorized as an alternative education because it fulfills additional needs of religious knowledge and it is independent in developing its education system for students. Indonesia has been using pondok pesantren to convey and bequeath Islamic values and teachings. Pondok pesantrens have at least for elements: Kiai as the central figure, ustads as teachers, santris as students, pondok pesantren as dormitory and mosque or mesjid as the center of activities.

For students, the main rationale of attending pondok pesantren was to gain the blessings of Allah. Therefore, a certificate of learning graduation was not given adequate attention, and there was not a precise regulation regarding the study program (Jumhur, 2011). Students learn how to be a good Muslim who obeys God's commands; have good characters; be independent; and demonstrate strong and comprehensive personal intellectuality.

A pondok pesantren has Kiai as the central figure. A kiai becomes the role model for all students and ustads. The Kiai is not only a spiritual leader, but also a holistic leader in all aspects of life in pondok pesantren (Jumhur, 2012). Everything the kiai does could be imitated by students. The kiai must be good man who can show the real obedience upon God's commands and ovoid any prohibitions from Him. 
In Madani Pesantre, the Kiai was Kiai

Rais. He is described as the role model for all

members of Madani Pesantre and he also becomes an educator with full knowledge and experiences. Kiai Rais, as the leader and role model of Madani Pesntren (MP), always gives religious advises for all students at MP and motivate them in seeking knowledge. The description upon Kiai Rais can be seen in the following quotations:

"He's our Kiai. Kiai Rais, the role model for all of us during our time here at MP. He is an educator with full knowledge and experiences. He went to school at Al-Hazhar, Medina, and in the Netherlands," said raja.

The way Kiai Rais motivates all students to seek knowledge can be seen in the following quotation:

"My children. Starting today, put an intention in your hearts. Intend to study because of Allah, lillahi ta'ala. Do you want to make this intention?" Kiai Rais gives advice to his students.

\section{Madani Pesantren Strategies to Develop Students' Characters}

\section{a. Enforce the regulations}

The excellence of MP in building students' awareness on discipline and independence is harsh law enforcement.
Every erroneous doing catch punishments soon. Those experiences can be seen in the following quotation;

"You six, Listen. The beginning lawlessness is when people belittle the rules and law is not enforced. It's different here. All wrongdoings should be paid immediately with punishment. As new students, you should take this principle to heart. Therefore, upon considering your wrongdoing, this court will add to your punishment as deterrent," said Tyson in a serious voice (Fuady, 2011: 69).

The quotation above explains clearly

how the strict regulation is really enforced.

Besides, System of examination is very strict.

Students should face written and oral examinations; students should learn independently to prepare the examinations.

This system can evade any cheatings.

Even though I was already revved up form Kiai Rais' motivational talk, I still had butterflies about my exams. This was quite different from all other exam I'd had before. And the load felt double, because they were oral and witten (Fuady, 2011: 182)

\section{b. Maximizing the roles of teachers}

The teachers develop into the real model for students. The teachers can make emotionally close relationship to students. To 
attach the teachers to students, Madani Pesantren give students homeroom teachers whom they can ask or share any problems. The following quotation describes homeroom teachers do their job well;

Ustad Salman came into the class one night carrying a pile of thick books. "To night we will spen our time going around the world," he said with 10centimeter smile... "Man shabara zhafira. He who is patient will be fortune. Don't worry about today's suffering just live on and see what will happen next. Because what we aim for is not for now, but there is something greater and more principle, to be man who has found his mission in life," he spoke with fiery passion (Fuady, 2011: 100)

According the quotation above, Ustad

Salman as one of homeroom teachers try to motivate students after they get tired of learning in Madani Pesantren. Then Ustad Salman keeps motivating them all as reflected the quotation below;

"Akhi do you what makes successful person different than ordinary people? According to a book I'm reading, there are two things most important in preparing yourself for success. One is going extra miles. Never settle for average. If people study for one hour, study for five. If others run two kilometers, run three. If people give up in 10 seconds, don't give up until 20," (Fuady, 2011: 100).

\section{Students' Characters Building in} Pesantren Madani

a. Trustworthiness

Trustworthiness is a behavior that tends to be honest, reliable, loyal, and do right things (Josephson Institute, 2012). This character demonstrates that people must articulate honestly, and be good to act everything. The writer finds the character is developed through being honest, loyal, reliable, and doing good things as following quotation when Alif was interviewing Ustad Khalid who just had finish Doctoral program from Egypt:

"What made you come back to MP?" I asked trying to uncover his motivation.

"A good question, Akhi. It's like this. I personally have decided to donate to MP. And the item I am donating is myself."

"Sorry Ustad, can you explain one more time, donate yourself?"

"Yes, simply speaking, if we donate land to the school, that land is forever in the hands for the school, for the sake of the school and its community. And for me, since I don't have land, what I am donating is myself."

From this quotation, the teacherUstad Khalid becomes the example to keep trustworthiness. It's hard to find somebody 
who can donate himself and his life totally for the institution. He wants to sacrifice his life for MP.

\section{b. Respect}

Respect is the way people show tolerance, accepting of differences, good manners and peace. These are certainly aspects of life that all of us craven. Respect is the mutually cooperative behavior between two or more people. It involves affection and friendship in times of need or crisis.

Students of Madani Pesantren could learn to respect people by making more friends. The students come from different tribes and backgrounds. The Fellowship of Manara consists of Alif from Maninjau, Atang from Bandung, Raja from Medan, Said from Surabaya, Baso from Sulawesi, Dulamajjid from Madura. Students learn tolerance and diversity without considering the backgrounds of their frieds.

After introducing himself, Ustad Salman asked each student to come up in front of class and present their name, where they came from, why they chose to come to the pesantren and their goals. Raja Lubis sitting at the front desk came up full of confidence... Raja, from outside of Medan... The biggest creature in the class was Said Jufri from Surabaya... "I'm from Sulawesi" said Baso Salahudin, who sailed from Sulawesi... Another friend was Dulmajid from Madura... the friend sitting behind me was Teuku. This dark skinned boy was from Banda Aceh (Fuady, 2011: 43-44).

c. Responsibility

Students learn how to be accountable upon their actions and themselves. Every wrong doing will get punishment with strict rule enforcement. In addition, students are also given responsibility to help protection in keeping Madani Pesantren secure from thieves or robbers. Alif and his friends ever got responsibility to be night patrol. In fulfilling this responsibility, they were not allowed to sleep even if just a moment and they also had to stay in their position until dawn came.

Tyson reminded us to night that... "Brothers, to night you need to be extra vigilant. According to police, this is robbery season." Dulmajid and I were assigned at the very edge of PM (Fuady, 2011: 226-227). 
Through this novel shows the way MP constructs the importance of self-discipline.

Discipline just can be implemented if we have tight schedule in which we don't have any time to waste. The value of discipline is presented by daily schedule of Madi Pesentren through Alif's letter for his mother.

“04.00-05.30

Our activities every day start at 04.00 in the morning for prayer, language practice, vocabulary building, and along with reading Qur'an.

05.30-07.00

Free time. It is used to develop our talents, wash clothes, and eat breakfast.

07.00-12.30

Morning class, you can't be late even a little bit late.

12.30-14.00

Zuhur prayer, and lunch.

14.00-14.45

Afternoon class.

14.45-15.30

Reading Qur'an and Ashar prayer

15.30-17.15

Free time for sport, bathing, and washing.

17.15-18.30

Reading Qur'an and communal prayer.

18.30-19.30

Eat dinner

19.00-20.00

Isya Prayer.

20.00-22.00

Night study led by the homeroom teacher (Fuadi, 2011: 136-13)"

This novel also teaches that discipline

can be enforced if there is no tolerance for any violation-big or small. This value is presented by the guard of MP. When Alif and his friends are late to attend reading Qur'an even just five minutes, the guard still gives

them punishment.

Alif says "Sorry, sorry, we are late. But only five minutes. We had to carry these heavy cabinets..."

"you are now at Madani, there is no such thing as a little late. One minute or one hour, late is late."

"Hey, wait a minute. You'll still be punished. At Madani, there are no wrongdoing that can go without punishment." (Fuadi, 2012: 62-63).

\section{d. Caring}

Students also learn to care their

friends. It comes naturally. They give their attention to their friends' conditions. The finding of how students could care to their friends can be portrayed from Alif's case. When Alif felt down because of the letter from Randai, his friends tried to entertain him.

For the past few days, I'd been feeling like a rock was weighing down on my chest... Seeing me so quite, Said and Dulmajid whipped out their broken Arabic, while Dulmajid whipped out his stash of "Dei Laughing the Madurese Wasy" stories. The everserious Baso tried to sing some Arabic poetry that said could cure a restless heart (Fuady, 2011: 98).

e. Justice and Leadership

Justice is applied in implementing the rules pf pesantren. If anyone 
contravenes that rules, he must get punishment without exception. Everyone is equal before the law. "Second, the news is also waited but the worry is announcement anyone who should face the court security, education and language to be punished according mistake. Almost certainly, who called is convict guilty." (Fuadi $2011:$ 62)

f. Humble/Sincerity

Students learn to live with humble or sincerity. Being humble helps them to be noble. They can understand that success should be achieved even it is not luxury.

“.....Think to feel the power of this humble principle. Remember, the winner and the success people that was far less than that does not succeed....." (Fuadi, 2011: 319)

g. Solidarity

Solidarity is portrayed from Baso's experience when he should return home to take care his grandmother. His friends continue his idealism to have stage performance entitled " Ibnu Batutah".

"....They are also success to perform very well. (Fuadi, 2011: 248)

h. Learning Natural Law

Kyai Rais advices his santris one upon a time by stating:

"...Put the intention vigorously, trying hard, and pray fervently, eventually what you strive to succeed. It is Sunnatullah-natural law". (Fuadi, 2011: 136).

\section{CONCLUSION}

Madani Pesantren can fulfill its role to develop students' characters. Using its system, students can involve themselves to make their characters noble. Students may learn diversity and respect from each other. Then they also get responsibility upon a certain thing and accomplish it as well as possible. The rules are very strict and enforced well. Moreover, Madani Pesantren also maximizes the roles of teachers by putting them as homeroom teachers who always motivate all students, make emotional relation among them and emotional attachment to the school. Finally the students can put friendship, responsibility, caring, discipline, solidarity, sincerity and natural law in their minds. In this Pesantren the character education works effectively.

\section{REFERENCE}

Anasom. 2000. Kebijakan Pemerintah Orde Baru Terhadap Pendidikan Islam. Semarang: IAIN Walisongo Semarang.

Hoosen, Sharah. 2012. Survey on Governments' Open Educational Resources (OER) Policies. British: Commonwealth of Learning.

Jennifer E., Sisk, M.A. 2012. Alternative School - Definition, Purpose, Description http://www.healthofchild 
ren.com/A/Alternative-

School.html\#b\#ixzz2AInKqi7y

Johan, Mohamad. 2012. The Implementation of Character Education At Pondok Pesantren (Case Study At Tarbiyatul Mu'allimien Al-Islamiyah [TMI] Pondok Pesantren Al-Amien Prenduan Sumenep). Thesis Graduate Programs, UIN Maulana Malik Ibrahim Malang.

Jumhur. 2011. Dynamic of Pondok Pesantren as Indegenous Islamic Education Centre In Indonesia. http://tsaqafah.isid.gontor.ac.id/volu me-vii-1/dynamic-of-pondokpesantren-as-indegenous-islamiceducation-centre-in-indonesia.html (downloaded, on 21th October).

Lickona, Thomas, 1992. Educating for Character: how our schools can teach respect and responsibility. New York: Bantam Books.

Marvin W. Berkowitz and Melinda C. Bier, 2004. Research-Based Character Education, The ANNALS of the American Academy of Political and Social Science

Mudyaharjo, Redja. 2006. Pengantar Pendidikan Sebuah Studi Awal tentang Dasar-dasar Pendidikan pada Umumnya dan Pendidikan di Indonesia. Jakarta: Rajawali Press.

Pimpinan Pusat Muhammadiyah, 2009, Revitalisasi Visi dan Karakter Bangsa, Agenda Indonesia ke Depan. P.20

Power, F. C., A. H. Higgins, and L. Kohlberg. 1989. Lawrence Kohlberg's approach to moral education. New York: Columbia University Press.
Saghafi, Ahmad and Shatalebi, Badri. 2012. Analyzing the Role of Teachers in The Nature Character Education Of Students From The Attitudes Of Them. Iran: Arabian Journal of Business and Management Review.

Sekhar, Savanam Chandra and Emmaniel, R. 2012. Impart Value-Based Education. India: International Journal of Academic Research in Progressive Education and Development January 2012, Vol. 1, No. 1.

Sheikh, Muhammad Ayoob and Abbassi, Zareen. 2007. Educational Approach to Character Building: A Paradigm Shift. Pakistan: the Institute of Business and Technology (BIZTEK).

Nasution, Faisal. 2009. Moral Values as Reflected in the Film "The Spongebob Square pants Movie". Yogyakarta: Faculty of Letters, English letters Study Program Ahmad Dahlan University.

Tomy. 2012. Kebijakan Pendidikan Islam Indonesia Masa Penjajahan ,Orla, Orba Dan Reformasi. http://ybasthomi.blogspot.com/2012/ 05/normal-0-false-false-false-in-xnone-ar.html 